\title{
Bilateral Herpes Simplex Keratitis Presenting as Bilateral Ulcerative Blepharo-Keratoconjunctivitis: A Rarity or Pattern
}

\author{
Charles S Zwerling ${ }^{1 *}$ and Rizul Naithani ${ }^{2}$ \\ ${ }^{1}$ Associate Professor of Surgery, Campbell University School of Osteopathic Medicine, USA \\ ${ }^{2}$ Campbell University School of Osteopathic Medicine, Class of 2021, USA
}

Submission: January 21, 2021; Published: January 28, 2021

*Corresponding author: Charles S Zwerling MD, 2709 Medical Office Place, Goldsboro, NC, USA

\begin{abstract}
We report a case of an immunocompetent 77-year-old Caucasian female presenting with bilateral herpes simplex keratitis masquerading as bilateral ulcerative blepharo-keratoconjunctivitis. Most cases of herpes simplex keratitis present unilaterally and uncommon occurrences of bilateral cases range from $1.3 \%$ to $10.9 \%$. In literature, bilateral herpes simplex keratitis has been reported for patients with atopic disease, corticosteroid use, autoimmune diseases, and UV A light exposure. Our patient had none of these conditions, but she did suffer from type 2 diabetes mellitus that was well-controlled. She had no prior history of known herpes simplex disease and tested negative for COVID 19. To date, this is the third reported bilateral herpes simplex keratitis case and the second reported in an elderly patient with shared history of prostaglandin usage and presence of diabetes mellitus. Our rationale for reporting this case is that while it seems to be a rare presentation it could be establishing a pattern. The study explores the relationship between a prostaglandin and HSV activation that may allow viral entrance due to epithelial breakdown. Since our patient did not have any of the previously reported immunocompromised states that have been associated with bilateral herpes keratitis, this case may represent a new pattern for HSV infection. Our clinical methods indicate that close follow-up was crucial to identifying the patient's eye condition as a bilateral herpes simplex keratitis. Due to this potential pattern of disease, a revised management approach may benefit similar patients by selecting alternative treatments for glaucoma early in the disease presentation.
\end{abstract}

Keyword: Herpes simplex; Dendrite; Corneal ulcer; Blepharo-keratoconjuncitivitis; Peripheral ulcerative keratitis; Prostaglandin

Abbreviations: HSK: Herpes Simplex Keratitis; PCR: Polymerase Chain Reaction

\section{Introduction}

The purpose of this paper is to report a rare case of bilateral Herpes simplex keratitis (HSK) masquerading as bilateral ulcerative blepharo-keratoconjunctivitis and consider a potential pattern of disease between herpes simplex keratitis and prostaglandin use. The Herpes simplex virus is a linear doublestranded DNA virus that is an Alphaherpesvirinae member of the Herpesviridae family. While the virus can infect any part of the body, it commonly infects the mouth, genitals and eyes. Ocular herpes can be caused by both HSV-1 and HSV-2 but HSV-1 is the most common etiology. Each year, there are close to 50,000 new and recurring cases of ocular HSV (predominantly type 1) [1]. Approximately 500,000 people in the United States have ocular HSV and the cost for treatment of new and recurrent cases is US $\$ 17.7$ million per year [2]. HSV is a neurotrophic virus meaning that it can remain latent in sensory and autonomic ganglia where it can reactivate for the lifetime of the host. While herpes simplex virus accounts for many types of ocular diseases, the most common infectious cause of blindness in developed nations is herpetic keratitis, an infection of the cornea. Transmission of HSV-1 is through direct contact of oral secretions or skin sores. Typically, HSV Keratitis is a reactivation of a dormant HSV-1 infection. Like herpetic cold sores, reactivation tends to occur most often during times of emotional or physical stress and especially in immuneincompetent hosts. Recurrent or untreated HSV keratitis may cause corneal scarring, meta=herpetic and neurotropic ulcers. Presentation of HSV is clinically unilateral and in rare cases of the immunocompromised a bilateral presentation may occur. Treatment usually involves topical anti-viral medications. Steroids may be used cautiously in some cases to limit corneal scarring; however, with neuroptic ulcer formation there is a risk for corneal melting and perforation. Frequent follow-up and compliance with medication regimens is crucial. Diagnosis, treatment and follow-up recommendations have been discussed with the patient including surgical intervention with aminograft [3]. 


\section{Materials and Methods}

\section{Initial Presentation of bilateral kerato-conjunctivitis}

On May 4, 2020 a 77-year-old white female presented to Goldsboro Eye Clinic with a 4-day history of red painful eyes with markedly decreased vision bilaterally. The patient self-treated with over the counter allergy eye drops without improvement. She denied any itching or allergy type symptoms. Her eye history includes chronic open angle glaucoma under control with Travatan $\mathrm{Z}$ and previous history of bilateral diabetic retinopathy managed with focal laser treatment. She has been a well-controlled Type II diabetic with hypertension with no other systemic illness or disease. On examination her best visual acuity was 20/400 OU. IOP was deferred due to the marked keratitis. External exam revealed marked bilateral blepharitis of the lower eye lids. Slit lamp exam demonstrated bilateral limbal ulcerative defects with significant corneal edema and +3 conjunctival injection. There appeared to be no cells or flare in the anterior chamber and there was mild +1 nuclear sclerotic cataracts present. Dilated fundus exam demonstrated mild diabetic retinopathy. Visibility was hindered by the corneal pathology. Treatment plan included topical Tobradex ophthalmic solution every 2 hours, Tobradex ophthalmic ointment at bedtime, and warm compresses. Travatan $\mathrm{Z}$ was continued as directed at bedtime. On May 6, 2020 the patient was re-examined with marked improvement in comfort and vision. Her visual acuity had improved to $20 / 60$ OU and IOP readings were 14 and 15 . The conjunctival injection had decreased to +2 and the inferior corneal ulceration and secondary corneal edema also improved.

\section{Presence of bilateral dendritic herpes simplex}

On May 8, 2020 patient was examined with further visual improvement and comfort. Her vision was 20/50 and 20/40 with IOP measured at 15 and 15. She demonstrated mild paracentral SPK, markedly reduced corneal edema and the presence of dendritic appearing lesions OU at the location of the resolving inferior ulcerative corneal defect with +1 conjunctival inflammation. The patient was asked if she had any recent or current history of URI, oral cold sores and/or fever blisters. She denied any such history. She denied any history of herpetic disease and/or immune problems. As a precaution, blood testing was performed and was negative for ANA. Herpes simplex virus (HSV) antigen was identified in both eyes using polymerase chain reaction (PCR). A COVID 19 test was negative. The patient continued the Tobradex medication and was started on Viroptic 5 times per day and oral Famvir 500mg per day.

On May 11, 2020 the patient was examined with further visual improvement and significant reduction in ocular inflammation. Her vision was 20/40 and 20/30. IOP was 22 and 17. Her conjunctival and eyelid margin inflammation were resolved, and her dendritic lesions demonstrated reduction in size and number. There was minimal corneal edema and no evidence of anterior or posterior segment inflammation. The Tobradex medication was stopped and replaced with Durezol QID OU. She continued the Viroptic 5 times a day and oral Famvir.

On May 14, 2020 the patient's vision had improved to 20/300U and IOP was 23 and 17. There was no ocular inflammation. Slit lamp revealed marked reduction of the dendrites in both eyes. The patient was instructed to continue her Viroptic and Famvir and reduce her Durezol to TID OU.

On May 21, 2020 the patient returned for follow-up with no complaints. Her best visual acuity was $20 / 300$ U and IOP was 20 and 15. Slit lamp revealed resolution of all dendrites and signs of mild subepithelial opacities. She was told to reduce her Durezol to BID and reduce her Viroptic to QID OU.

On May 28, 2020 the patient returned with no complaints. Her best visual acuity remained at 20/300U and IOP was 17 and 19 . OU cornea were clear with signs of mild opacity noted at the site of the previous dendritic formations. She was instructed to titrate to discontinue her Durezol and Viroptic over the next week (Figure 1).
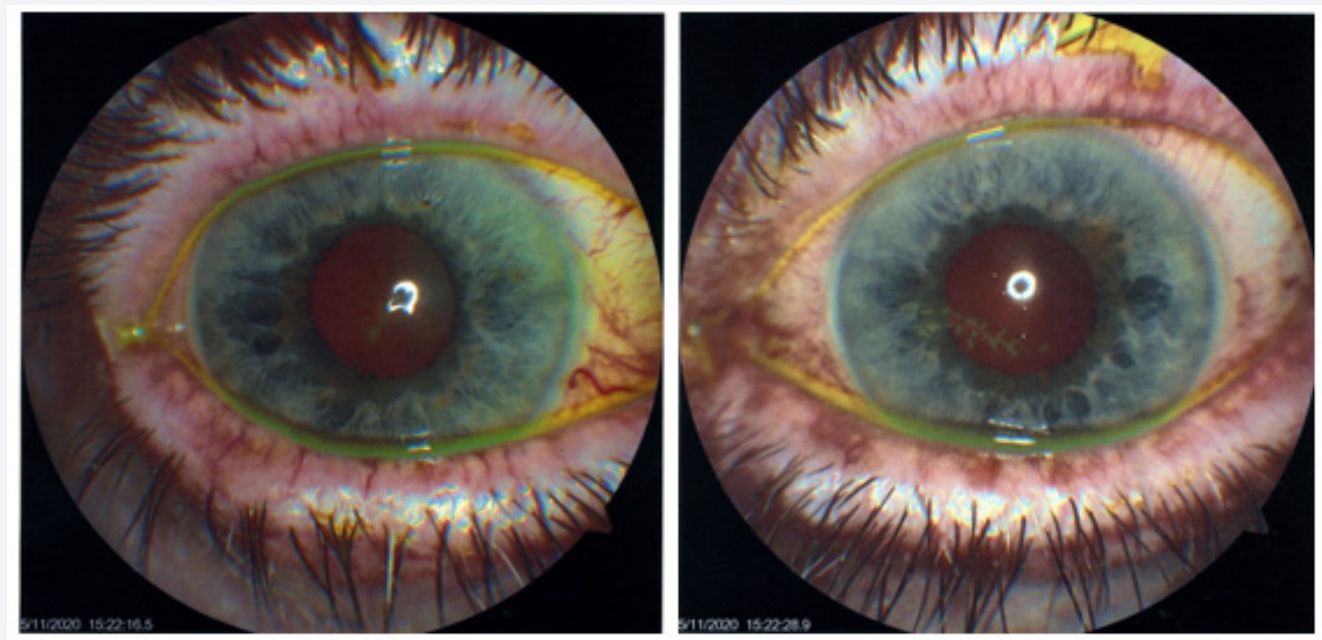

Figure 1: a) OD with dendritic paracentral herpes keratitis b) OS with dendritic paracentral herpes keratitis. 


\section{Resolution of bilateral herpes simplex}

On June 4, 2020 the patient returned for further follow up with no complaints. Her best vision was 20/300U and IOP was 17 OU. There was no ocular inflammation and slit lamp exam revealed no active corneal lesions with no dye uptake. She was told to discontinue her Famvir and continue her Travatan as usual.

On July 14, 2020 the patient returned with no complaints of any eye pain and/or inflammation. Her best vision was 20/400D and $20 / 500$ S and IOP was 140 U. There was no ocular inflammation and slit lamp exam revealed no active corneal lesions with negative dye uptake at the previous dendritic areas. She was told to finish her Famvir, Viroptic, and continue to use her Travatan.

\section{Re-occurrence of bilateral herpes simplex}

On August 24, 2020 the patient returned with a new complaint of bilateral eye pain and redness. Her vision had decreased to 20/700U and IOP was 130D and 100S. Slit lamp exam revealed $=3$ injection with bilateral dye uptake in a dendritic pattern OS $>0 D$.

Table 1: Summary of studies with bilateral herpetic keratitis.
She was told to stop her Travatan and start Alphagan P BID OU. She was also instructed to resume her Famvir 500mg qd and Viroptic $5 \mathrm{X} /$ per day OU medications.

On August 28, 2020 the patient returned with marked improvement. Her vision was 20/500U and IOP of 170D and 120S. Her conjunctival inflammation was $<+10 U$ and there was marked reduction in the keratitis to a few scattered SPK OU. Her Viroptic was reduced to QID OU and she was told to continue her Famvir qd.

\section{Resolution of bilateral herpes simplex}

On August 31, 2020 the patient returned with no complaints. Her vision was $20 / 400 D$ and 20/500S. Her IOP was $160 D$ and 130S. There was no inflammation and no dye uptake in either eye. She was told to stop her Famvir and Viroptic and continue to use the Alphagan BID OU. On September 8, 2020 the patient returned with no complaints. Her vision was $20 / 300 D$ and $20 / 400$ S. IOP was $100 \mathrm{D}$ and $120 \mathrm{~S}$. She was scheduled to return in 3 months or prn (Table 1).

\begin{tabular}{|c|c|c|c|c|}
\hline Study & Setting & $\begin{array}{l}\text { \# of Bilateral } \\
\text { HSV Eye } \\
\text { Cases }\end{array}$ & Description of Bilateral HSV Keratitis Cases & Management \\
\hline $\begin{array}{c}\text { Bilateral herpetic kerato- } \\
\text { conjunctivitis, Souza PM } \\
{[10]}\end{array}$ & $\begin{array}{l}\text { Retrospective (Jan } \\
\text { 1996-Sep 2001) } \\
\text { in Department of } \\
\text { Ophthalmology } \\
\text { University of Min- } \\
\text { nesota. }\end{array}$ & $7 / 544(1.3 \%)$ & $\begin{array}{c}\text {-Age: } 7 \text { weeks }-46 \text { yo } \\
-5 \text { pts systemic atopy } \\
-2 \text { patients had severe ocular rosacea. } \\
-2 \text { had systemic immune disorders }\end{array}$ & $\begin{array}{l}\text { Long-term prophylactic anti- } \\
\text { viral treatment reduced recur- } \\
\text { rence (average remission in } 4 \\
\text { patients was } 1.7 \text { years) }\end{array}$ \\
\hline $\begin{array}{l}\text { Wilhelmus, K. "Bilateral } \\
\text { herpetic keratitis". }\end{array}$ & $\begin{array}{c}\text { Virus Clinic (Moor- } \\
\text { fields Eye Hospital } \\
\text { UK) } \\
\text { https://www. } \\
\text { ncbi.nlm.nih.gov/ } \\
\text { pmc/articles/ } \\
\text { PMC1039529/ } \\
\text { pdf/brjop- } \\
\text { thal00186-0015. } \\
\text { pdf }\end{array}$ & $\begin{array}{c}30 / 1000 \\
(3 \%)\end{array}$ & $\begin{array}{c}-21 \text { patients }(70 \%)=\text { male and } 9 \text { patients (30\%) } \\
\text { = female } \\
\text {-average age initial episode } 28+/-15 \text { years } \\
\text { (range } 5-60 \text { yo) } \\
\text {-Immediately preceding initial keratitis epi- } \\
\text { sode= } 4 \text { patients had systemic illness (malaria/ } \\
\text { pulmonary tb/lumbar herpes zoster/gastric } \\
\text { carcinoma) } \\
-12 \text { patients (40\%) had atopy } \\
-1 \text { patient receiving topical corticosteroid when } \\
\text { they developed bilateral herpetic keratitis } \\
-17 \text { patients (57\%) had simultaneous bilateral } \\
\text { primary infection. } \\
\text {-13 patients had bilateral involvement on sepa- } \\
\text { rate occasions } \\
-7 \text { (23\%) had cutaneous vesicles (lid, nose, lip) } \\
-1 \text { had lid vesicles } \\
-6(20 \%) \text { had follicular conjunctivitis } \\
\text {-article notes patients tend to be younger and } \\
\text { have atopy compared to unilateral group }\end{array}$ & $\begin{array}{c}4 \text { atopic patients had sec- } \\
\text { ondary microbial keratitis } \\
\text { (1 had suppurative keratitis } \\
\text { due to staphylococcus aureus, } \\
\text { the other } 3 \text { patients had S. } \\
\text { aureus/ Pseudomonas aerugi- } \\
\text { nosa/ Candida albicans) } \\
\text {-higher subsequent compli- } \\
\text { cations (recurrent ulcerative } \\
\text { keratitis } 68 \% \text { and subsequent } \\
\text { disciform stromal keratitis } \\
40 \%)\end{array}$ \\
\hline
\end{tabular}




\begin{tabular}{|c|c|c|c|c|}
\hline $\begin{array}{l}\text { "A case of simultaneous bi- } \\
\text { lateral herpetic epithelial } \\
\text { keratitis" Fan CC [11] }\end{array}$ & Japanese & Case report & $\begin{array}{c}\text { Pathogen: HSV-1 both eyes } \\
37 \text { yo male chronic atopic dermatitis form } \\
\text { Kaposi's varicelliform eruption and bilateral } \\
\text { dendritic epithelial keratitis with corneal epi- } \\
\text { thelial edema }\end{array}$ & \\
\hline $\begin{array}{l}\text { "Bilateral herpes simplex } \\
\text { keratitis presenting as } \\
\text { peripheral ulcerative kera- } \\
\text { titis" Anna Praidou [9] }\end{array}$ & & Case report & $\begin{array}{c}47 \text { yo female complaining of painful red eyes } \\
\text { with history of arthritis and anterior uveitis } \\
\text { attacks with pos ANA }\end{array}$ & \\
\hline $\begin{array}{l}\text { "Bilateral herpetic } \\
\text { keratitis presenting with } \\
\text { unilateral neurotrophic } \\
\text { keratitis in pemphigus } \\
\text { foliaceus: a case report" } \\
\text { Hee K Yang [19] }\end{array}$ & Korea & Case report & $\begin{array}{l}71 \text { yo Korean man bilateral herpetic keratitis } 1 \\
\text { week after rapid tapering of systemic cortico- } \\
\text { steroid (was on high-dose corticosteroid and } \\
\text { azathioprine therapy for } 6 \text { months to treat } \\
\text { pemphigus foliaceus). } \\
\text {-Correlation of steroid tapering and symptom } \\
\text { development and no blistering lesions on } \\
\text { cornea, herpetic ketatitis not complication of PF } \\
\text { but was a type of opportunistic infection } \\
\\
\text { Steroid use and rapid tapering are known risk } \\
\text { factors for recurrent herpetic keratitis. } \\
\text { - rapid tapering exacerbates inflammatory reac- } \\
\text { tions after primary opportunistic infections or } \\
\text { trigger reactivation of previous latent infections }\end{array}$ & $\begin{array}{l}\text { Oral acyclovir with topical } \\
\text { broad-spectrum antibiotics. } \\
\text { Complication while treat- } \\
\text { ment: after initial topical anti- } \\
\text { viral only right eye improved } \\
\text { but left worsened (left had } \\
\text { endothelitis or sterile ulcer). } \\
\text { Asymmetry uncommon in HS. } \\
\text { Oral antiviral resolved issue } \\
\text { (article reports asymmetry in } \\
\text { treatment response possible } \\
\text { due to underlying systemic } \\
\text { condition as patient was } \\
\text { immunocompromise) } \\
\text { Systemic antiviral used <9 } \\
\text { weeks and no recurrence a } \\
\text { year after }\end{array}$ \\
\hline $\begin{array}{l}\text { "Recurrence of bilateral } \\
\text { herpes simplex virus kera- } \\
\text { titis following bimatoprost } \\
\text { use" Mihir Trilok Kothari } \\
\text { [7] }\end{array}$ & $\begin{array}{l}\text { Glaucoma Service, } \\
\text { Bombay City Eye } \\
\text { Institute and } \\
\text { Research Center } \\
\text { (India) }\end{array}$ & Case report & $\begin{array}{l}76 \text { yo male with recurrence of bilateral HSV } \\
\text { keratitis following use of } 0.03 \% \text { Bimatoprost } \\
\text { (Lumigan) eye drops for uncontrolled intraoc- } \\
\text { ular pressure in bilateral primary open-angle } \\
\text { glaucoma. Possibly prostaglandin mediated } \\
\text {-PMH included noninsulin-dependent diabetes } \\
\text { mellitus, essential hypertension, acute myo- } \\
\text { cardial infarction, and coronary artery bypass } \\
\text { grafting } \\
\text {-PSH included cataract extraction and trab- } \\
\text { eculectomy in left eye. PMH included type } 2 \\
\text { diabetes, essential hypertension, acute MI, } \\
\text { coronary artery bypass grafting. } \\
\text {-immature cataract in right eye and pseudopha- } \\
\text { kia with scarred bleb in left eye. Cup to disk on } \\
\text { both eye } 0.9 \\
\text { **Bimatoprost use started } 2001 \text { internationally, } \\
\text { only } 1 \text { case associated with its use and recur- } \\
\text { rence of HSV keratitis. }\end{array}$ & $\begin{array}{l}\text { Switched patient to alphagan } \\
(0.3 \% \text { brimonidine) with no } \\
\text { recurrence of HK a year later }\end{array}$ \\
\hline $\begin{array}{l}\text { "Bilateral viral keratitis } \\
\text { following corneal collagen } \\
\text { crosslinking for progres- } \\
\text { sive keratoconus" Sanjeeta } \\
\text { Sitaula [6] }\end{array}$ & India & Case report & $\begin{array}{l}18 \text { yo male had corneal collagen crosslinking in } \\
\text { both eyes for bilateral progressive keratoconus, } \\
7 \text { days later central corneal lesion in both eyes } \\
\text { (bilateral viral keratitis) } \\
\text {-Ultraviolet A light possible stimulus in HSV } \\
\text { reactivation } \\
\text {-PMH: no past redness, atopy, or viral infection } \\
\text { in any eyes before. Immunocompetent. No } \\
\text { underlying systemic disease }\end{array}$ & $\begin{array}{c}\text { Dendrite healed completely in } \\
10 \text { days with oral and topical } \\
\text { acyclovir treatment }\end{array}$ \\
\hline
\end{tabular}




\begin{tabular}{|c|c|c|c|c|}
\hline $\begin{array}{c}\text { "Latanoprost and herpes } \\
\text { simplex keratitis" M Wand } \\
\text { [14] }\end{array}$ & $\begin{array}{l}3 \text { cases in which } \\
\text { HSV keratitis de- } \\
\text { veloped after initia- } \\
\text { tion of latanoprost }\end{array}$ & $\begin{array}{c}\text { Case series } \\
1 / 3\end{array}$ & $\begin{array}{l}\text {-One patient with bilateral recurrence with } \\
\text { latanoprost } \\
\text {-69 yo male open-angle glaucoma and previous } \\
\text { bilateral epithelial and stromal herpes simplex } \\
\text { keratitis treated with oral valacyclovir } \\
\text {-Latanoprost added in March } 1997 \text { to regimen } \\
\text { of betaxolol and pilocarpine in both eyes. With- } \\
\text { in } 1 \text { month dendritic herpes simplex keratitis in } \\
\text { left eye then right eye. } \\
\text {-PMH: open angle glaucoma and previous bilat- } \\
\text { eral epithelial and stromal HSV keratitis treated } \\
\text { with oral valacyclovir maintenance therapy }\end{array}$ & $\begin{array}{l}\text { Keratitis treated with topical } \\
\text { trifluridine but resolved slow- } \\
\text { ly with occasional recurrence. } \\
\text { Latanoprost had to be discon- } \\
\text { tinued for infection to clear. } \\
\text { Antiviral could not eradicate } \\
\text { herpes simplex keratitis } \\
\text { until latanoprost discontin- } \\
\text { ued. Intraocular pressure } \\
\text { remained high, requiring } \\
\text { glaucoma filtration surgery } \\
\text { with intraoperative mitomy- } \\
\text { cin. Post-surgery all eyedrops } \\
\text { discontinued in left eye as } \\
\text { pressures became controlled } \\
\text { and no HSV keratitis recur- } \\
\text { rence but right eye continued } \\
\text { with dendritic episodes until } \\
\text { latanoprost was discontinued. } \\
\text { In the third case that was } \\
\text { not bilateral, reinstitution of } \\
\text { latanoprost with prophylactic } \\
\text { antiviral kept HSV suppressed } \\
\text { but as soon as antiviral was } \\
\text { discontinued, herpes simplex } \\
\text { keratitis reappeared }\end{array}$ \\
\hline
\end{tabular}

\section{Discussion}

HSV keratitis can be divided into two major types: epithelial disease and stromal disease. The epithelial disease is usually due to actively replicating virus while the more common stromal disease is often caused by immunologic mechanisms. A third type, endothelial keratitis, manifests as rejection line-like keratic precipitates and stromal edema [4]. Variations between these subtypes poses a big challenge in accurate diagnoses which is important as treatment methods are very distinct. Usually, herpes simplex keratitis presents unilaterally but bilateral cases have been reported in $1.3 \%$ to $10.9 \%$ of patients [5]. Bilateral presentation can develop in immunocompromised patients such as those suffering from congenital immune deficiencies, atopy, or long-term immunosuppression [5].

Our case report involved an immunocompetent Type II diabetic elderly patient with bilateral herpes simplex keratitis that presented as bilateral ulcerative blepharo-keratoconjunctivitis. Initially, the patient was treated for a presumed bacterial infection involving her eye lid margins, conjunctiva and cornea. She had no previous history of herpetic infections or symptoms and had a healthy immune system on presentation. Our case is also interesting because most case reports of bilateral herpetic keratitis in immunocompetent individuals have been reported in the young [6]; and without other immunosuppressive diseases besides diabetes in our patient, our case seems to be a rare anomaly for an elderly patient. It could be argued that amidst COVID-19, this patient may have been suffering from the virus mild enough to not recognize any symptoms and this could have created opportunity for HSV-1 to reactivate. This pathophsiology should be considered, since COVID-19 testing has reported a 38\% false negative rate for the disease [7]. However, this patient did not have any commonly known COVID-19 symptoms that could be linked with the immunosuppression that could explain bilateral HSV keratitis presentation. For more thorough assessment, a follow-up on COVID-19 antibodies for unusual presentation of COVID-19 would be worth investigating. It would also help challenge any argument for immunosuppression beyond the patient's established medical conditions. Upon further inspection of our patient's history, it was acknowledged that the patient was on a prostaglandin analog used for treatment of the patient's chronic open angle glaucoma. This information is valuable to acknowledge as a possible cause for our patient's presentation, because there has been another reported case where a 76-year-old male had recurrence of bilateral HSV keratitis following the use of $0.03 \%$ Bimatoprost eye drops [8].

\section{Ocular adverse reactions of prostaglandins}

The most common adverse reaction observed was ocular hyperemia in 30 to $50 \%$ of patients [9]. Up to $3 \%$ of patients discontinued therapy due to conjunctival hyperemia9. Mild ocular adverse reactions reported at an incidence of 5 to $10 \%$ in clinical studies and included decreased visual acuity, eye discomfort, foreign body sensation, pain and pruritus. More serious ocular adverse reactions reported at an incidence of 1 to $4 \%$ in clinical studies included abnormal vision, blepharitis, blurred vision, cataract, conjunctivitis, corneal staining, dry eye, iris discoloration, keratitis, periorbital and lid changes including deepening of the eyelid sulcus, lid margin crusting, ocular inflammation, photophobia, subconjunctival hemorrhage and tearing [9]. 


\section{Non-ocular adverse reactions of prostaglandins}

Non-ocular adverse reactions reported at an incidence of 1 to $5 \%$ in these clinical studies were allergy, angina pectoris, anxiety, arthritis, back pain, bradycardia, bronchitis, chest pain, cold/ flu syndrome, depression, dyspepsia, gastrointestinal disorder, headache, hypercholesterolemia, hypertension, hypotension, infection, pain, prostate disorder, sinusitis, urinary incontinence and urinary tract infections [9]. Prostaglandin toxicity studies have widely documented the presence of dry eyes; however in a cross-sectional study, Teresa Rolle et al. [10] noted that tafluprost had no effect on tear stability compared to preservative-free timolol and that the active component of both groups can lead to ocular surface defects [10]. On the other hand, BAK concentrations in prostaglandin preservative solutions have been noted for dry eyes. BAK has been proven to quicken drying of tear film and aggravate preexisting dry eye. This was demonstrated in an openlabel multicentre study with 158 patients where preservative-free tafluprost was better tolerated compared to latanoprost containing preservative solution [11]. It is important to note, however, that a study by Jess T Whitson et al. [12] found no significant difference in tear break-up time and corneal staining among prostaglandins with different BAK concentrations which included bimatoprost (0.005\% BAK), latanoprost (0.02\% BAK), and travoprost (safZia) [12].

Continuing with the discussion of prostaglandin's mechanism to causing dry eyes, meibomian gland dysfunction has been an important etiology of dry eye and long-term topical medication of prostaglandins can lead of meibomian gland obstruction [13]. A study done by Luca et al. [14] observed significant morphological changes in meibomian glands through LSCM between preservative and preservative-free prostaglandin groups [14]. These studies lend themselves to suggest that we need a long-term investigation to understand tolerability of the ocular surface in the face of preservatives found in glaucoma medications such as prostaglandin [15-20].

Of note, this patient's medical history of diabetes mellitus alongside the use of a prostaglandin may have increased her likelihood of presenting with bilateral herpes keratitis. A systemic disease that weakens the immune system allowing for reactivation of the herpes virus and the continuous use of preservativecontaining prostaglandin in this circumstance could have brewed the perfect storm. While our patient presented in May and was being treated accordingly with antivirals, what was most peculiar was her recurrence in late August. When we switched her Alphagan, she rapidly improved in visual acuity and her pressures continued to be maintained. Our case documents one of the few cases documented where this has occurred in a diabetic patient, hence, it would be interesting to gather more data from the collective medical community if more instances have occurred but not documented in case reports. This is important because frequent follow-up of this patient was the key to identifying, modifying the treatment path, and resolving the disease of this patient [20-23].

\section{Conclusion}

Bilateral herpetic keratitis masquerading as a bilateral ulcerative blepharo-keratoconjuncitivitis is a rare presentation of herpetic disease. With no steroid use, atopic disease, COVID-19 infection, or recent immunosuppressive procedures, our case presents a rarity of reported for bilateral herpes simplex 1 reactivation and subsequent keratitis. Bilateral herpes simplex keratitis can pose a diagnostic dilemma in cases with a healthy immune system and no other systemic symptoms. Excluding other infectious agents is mandatory for appropriate treatment. Moreover, this case clearly established a causal relationship with topical prostaglandin use. Once the prostaglandin was removed, there was no reoccurrence. Additionally, the most important aspect to management of patients with rare disease occurrences is follow-up.

\section{References}

1. Gabrielle, Weiner (2013) Demystifying the Ocular Herpes Simplex Virus. American Academy of Ophthalmology.

2. Farooq AV, Shukla D (2012) Herpes simplex epithelial and stromal keratitis: an epidemiologic update. Surv Ophthalmol 57(5): 448-462.

3. Al-Dujaili LJ, Clerkin PP, Clement C (2011) Ocular herpes simplex virus: how are latency, reactivation, recurrent disease and therapy interrelated? Future Microbiol 6(8): 877-907.

4. Azher TN, Yin XT, Tajfirouz D, Huang AJ, Stuart PM (2017) Herpes simplex keratitis: challenges in diagnosis and clinical management. Clin Ophthalmol 11: 185-191.

5. Liesegang TJ (2001) Herpes simplex virus epidemiology and ocular importance. Cornea 20(1): 1-13.

6. Sitaula S, Singh SK, Gurung A (2019) Bilateral viral keratitis following corneal collagen crosslinking for progressive keratoconus. J Ophthalmic Inflamm Infect 9(1): 16 .

7. (2020) False Negatives Found If COVID-19 Testing Done too Soon.

8. Kothari MT, Mehta BK, Asher NS, Kothari KJ (2006) Recurrence of bilateral herpes simplex virus keratitis following bimatoprost use. Indian J Ophthalmol 54(1): 47-48.

9. Praidou A, Androudi S, Kanonidou E, Konidaris V, Alexandridis A, et al. (2012) Bilateral Herpes Simplex Keratitis Presenting as Peripheral Ulcerative Keratitis. Cornea: 31(5): 570-571.

10. Souza PM, Holland EJ, Huang AJ (2003) Bilateral herpetic keratoconjunctivitis. Ophthalmology 110(3): 493-496.

11. Fan CC, Shimomura Y, Inoue Y (1989) A case of simultaneous bilateral herpetic epithelial keratitis. Jpn J Ophthalmol 33(1): 120-124.

12. Maeno S, Koh S (2019) Bilateral Herpetic Keratitis in Atopic Dermatitis. Mayo Clin Proc 94(11): 2270-2271.

13. Wilhelmus K (1981) Bilateral herpetic keratitis. British Journal of Ophthalmology 65(6): 385-387.

14. Wand M, Gilbert CM, Liesegang TJ (1999) Latanoprost and herpes simplex keratitis. Am J Ophthalmol 127(5): 602-604.

15. Emily R (2017) Primary Bilateral Herpes Simplex Blepharitis in a 60 -year-old female with atopic disease. 
16. Agarwal R, Maharana PK, Titiyal JS (2019) Bilateral herpes simplex keratitis: lactation a trigger for recurrence! BMJ Case Reports CP 12(3): e223713

17. Yoshida M, Hosogai M, Yokokura S (2019) Bilateral Necrotizing Herpes Simplex Keratitis in an Immunocompetent Patient with Genetic Analysis of Herpes Simplex Virus 1. Cornea 38(9): 1185-1188.

18. Yang HK., Han YK, Wee WR (2011) Bilateral herpetic keratitis presenting with unilateral neurotrophic keratitis in pemphigus foliaceus: A case report. J Med Case Reports 5: 328.

19. Travatan Z (2019) (Travaprost Ophthalmic Solution): Uses, Dosage, Side Effects, Interactions, Warning.

20. Rolle T, Spinetta R Nuzzi R (2017) Long term safety and tolerability of Tafluprost $0.0015 \%$ vs. Timolol $0.1 \%$ preservative-free in ocular hypertensive and in primary open-angle glaucoma patients: a cross section study. BMC Ophthalmology 17(1): 136.

21. Mocan MC, Uzunosmanoglu E, Kocabeyoglu S, Karakaya J, Irkec M (2016) The association of chronic topical prostaglandin analog use with meibomian gland dysfunction. J Glaucoma 25(9): 770-774.

22. Luca A, Vincenzo F, Ciro C (2013) In vivo confocal microscopy of meibomian glands in glaucoma. British Journal of Ophthalmology 97(3): 343-349.

23. Whitson JT, Trattler WB, Matossian C, Williams J, Hollander DA (2019) Ocular surface tolerability of prostaglandin analogs in patients with glaucoma or ocular hypertension. Journal of Ocular Pharmacology and Therapeutics 26(3): 287-292.

\section{Your next submission with Juniper Publishers} will reach you the below assets

- Quality Editorial service

- Swift Peer Review

- Reprints availability

- E-prints Service

- Manuscript Podcast for convenient understanding

- Global attainment for your research

- Manuscript accessibility in different formats

( Pdf, E-pub, Full Text, Audio)

- Unceasing customer service

Track the below URL for one-step submission https://juniperpublishers.com/online-submission.php 